\title{
A bizarre Palissya ovulate organ from Upper Triassic strata of the Zixing coal field, Hunan Province, China
}

\author{
WANG ZiQiang* \\ Tianjin Institute of Geology and Mineral Resources, Chinese Academy of Geological Sciences, Tianjin 300170, China
}

Received November 5, 2011; accepted December 31, 2011; published online January 31, 2012

Palissya, a little-known reproductive organ with a long history, is recorded from China and Asia for the first time. A new species, Palissya hunanensis (sp. nov.), is described from the Upper Triassic Rhaetican strata of the Zixing coal field of Hunan Province. The ovulate cone has a compound shoot system that consists of a main axis and many helically-arranged axillary structures referred to as female dwarf shoots, each of which is subtended by a bract. Despite a superficial similarity, $P$. hunanensis differs from the typical species $P$. sphenolepis (Braun) Nathorst in a number of subtle but consistent features: the cone is much smaller and narrower, the bracts are much thinner, there are fewer pairs of cup-like seed scales, and the seed scales are adaxially attached to a thick axis rather than to bracts. These traits are all distinctly different from other species of the genus. Moreover, SEM observation of the new species reveals morphological features of the seed scales and seeds and details of the female dwarf shoot; significantly increases our knowledge of Palissya; and provides new evidence that it is a conifer. Palissya is related to the Lower Permian Lebowskia, a voltzian conifer bearing ovuliferous structures similar to the bract plus dwarf-shoot organization of Palissya. Palissya-type conifers probably grew in specialized marine-continent habitats, unlike most other extant and extinct conifers that grow in drier upland environments.

Palissya, conifer, female dwarf shoot, Rhaetican, Hunan of China

Citation: Wang Z Q. A bizarre Palissya ovulate organ from Upper Triassic strata of the Zixing coal field, Hunan Province, China. Chin Sci Bull, 2012, 57: 1169-1177, doi: 10.1007/s11434-012-4975-8

Palissya is a rare-found fossil genus of extinct plants that spanned short time interval in the Late Triassic (Rhaetican) age. It has a specialized reproductive structure, a compound shoot system that consists of a striate main axis with numerous helically arranged fertile bracts, plus lateral axes on which some pairs of seed-bearing structures are adaxially borne. Its distribution is extremely limited, with known fossils scattered in a few localities in the Northern Hemisphere, such as Sweden [1], Germany [2], and America, which also hosted a very similar conifer, Metridiostrobus palissyaeoides [3]. Palissya has also been recorded from some sites along the eastern Australia and New Zealand in the Southern Hemisphere [4,5]. The fossils were almost unanimously believed to be conifer ovulate cones, but unfortunately, its seeds have never been detected. The epidermal structures

*Corresponding author (email: tjzwq@yahoo.com.cn) were studied from some of the co-occurring sterile shoots rather than from the fertile bracts themselves.

The fascinating gross morphology of Palissya has attracted the attention of the world's paleobotanists for a century and a half, including such founders of the discipline as Braun, Saporta, Schimper, Solms-Laubach, Schenk, and Nathorst, among others [1,6]. Palissya has featured in many paleobotanical magnum opera representing different times [2,6-17]. Schenk, Nathorst, and Florin elaborated on the marvelous reproductive organ $[1,2,9]$. In the early 1930s, the Rhaetican-Liassican floras from marine-continental deposits were studied in detail; including Stachyotaxus, another member of Palissyaceae, and Palissya were discussed as rare but distinctive conifers of the floras [18]. Later, Florin precisely described both genera and suggested that they represented a type of conifer reproductive organs consisting of a structure he called a seed-scale complex plus a 
subtending bract $[2,8,9]$. However, even today, Palissya is a little known fossil plant.

During the last decades of the 20th century, Florin's interpretations of the Paleozoic walchian conifers were almost universally rejected $[19,20]$. As an indirect consequence, the importance of Palissya to taxonomy and systematics has been unjustly underestimated. Consequently, little to no attention has been paid to these intriguing fossils; in particular, none of the recent phylogenetic analyses to seed plants or gymnosperms has used the cladistic datasets of Palissya or Stachyotaxus [21-25]. In fact, most contributions on conifers do not cite the papers of Nathorst and Florin $[1,2,9]$ on the Palissyaceae.

Although Stachyotaxus has been proved to be a conifer on the basis of cone architecture, cutinized structures, seed microstructure, and male organs [7], most papers on fossil conifer systematics have excluded Palissya and Stachyotaxus from their data, and some have even questioned whether Palissya was a conifer [26,27]. As a reminiscence of warnings of Harris and others, Florin's monographs on conifers and taxads published during 1939-1944 need to spent time enough to study $[28,29]$.

Our present knowledge on Palissya is meager because of sampling bias. Only a small number of the published specimens have been examined to reconstruct the basic design of the complete reproductive organ. Indeed, total number of the specimens studied by all authors is extremely low, only having one or two from each locality to yield valuable information on the genus: only one well-preserved specimen in Florin's Plate 83-4, figure 20 from the German material [2]; one or two in Nathorst's Plate 1, Figure 1 from Swedish material [1]; and only one American specimen assigned to Metridiostrobus palissyaeoides [3]. Of the Southern continental material referred to as "Palissya" cones, fewer than 10 of the significant and identifiable specimens were illustrated from five or six localities along the eastern Australia and New Zealand [4].

\section{Fossil material}

The Palissya specimens reported here were collected in 1959, when the author, as a student of the Geology Department of Nanjing University, made a summer field expedition to Sandou Mine of the Zixing coal field, Hunan, but their publication at the time was precluded by a lack of photographic resolution. At a glance, these new Palissya specimens are not distinguishable from the European $P$. sphenolepis (Braun) Nathorst, but they actually differ from that species in many distinctive features and represent a new species. Although more than half a century has passed since their discovery, the small specimens are still of significance, because they represent the first convincing records of these intriguing plants in China, and Asia as well.

\section{Terminology}

In this paper, some terms not used in Florin's monographs are defined based on his original meanings (pp. 271-272) in the last edition on taxads and Palissyaceae [9]. They are:

main axis equates directly to Florin's main axis;

axis equates to Florin's axis of the completely (or almost completely) fertile seed-scale complex;

female dwarf shoot is based on Florin's description of some taxads, such as Palaeotaxus;

ovulate cone equates to Florin's female cone;

seed scale comes from Florin's fertile seed-scale complex; diplostichous is used after Florin's erecto-patent.

\section{Stratigraphic background}

The Zixing coal field of Hunan Province is an area of southern China where the Lower Mesozoic marine-continental deposits are exceptionally well developed [30], with a succession of coal-bearing strata comprising the Upper Triassic Chutanlong and Yangmeilong Formations, and the Lower Jurassic Tanlong, Maoxianling, and Shigu Formations in ascending sequence. Abundant marine bivalves and plant fossils have been recorded from the succession [30-32]. The fossil plants were examined by Prof. Zhou Zhiyan with three major plant-assemblage zones as follows (Figure 1):

(i) the Upper Triassic Ptilozamites-Anthrophyopsis assemblage zone of the Yangmeilong Formation;

(ii) the Lower Jurassic Otozamites-Sagenopteris assemblage zone of the Tanlong Formation;

(iii) the Lower Jurassic Coniopteris-Marattiopsis assemblage zone of the Shigu Formation.

The specimens of Palissya reported here came from a black, hard, and brittle carbonaceous shale bed of the Yangmeilong Formation in Sandou Mine, in the northern part of the Zixing coal field. Several very small, incomplete ovulate cones were preserved on an uneven surface of cleaved rock. This presentation was not favorable for photography with a traditional camera. All the plant remains were highly coalified, and no cuticle was obtained through maceration, but a few pieces of the remains could be observed under SEM microscopy.

Other fossil plants associated with the new Palissya species were Ptilozamites tenuis Oishi, Taeniopteris tenuinervis (Brown) Harris, Pterophyllum kochi Harris, Anomozamites cf. major Nathorst, Sphenobaiera sp., Glossophyllum? sp., and Equisetites sarrani Zeiller ${ }^{1}$. 


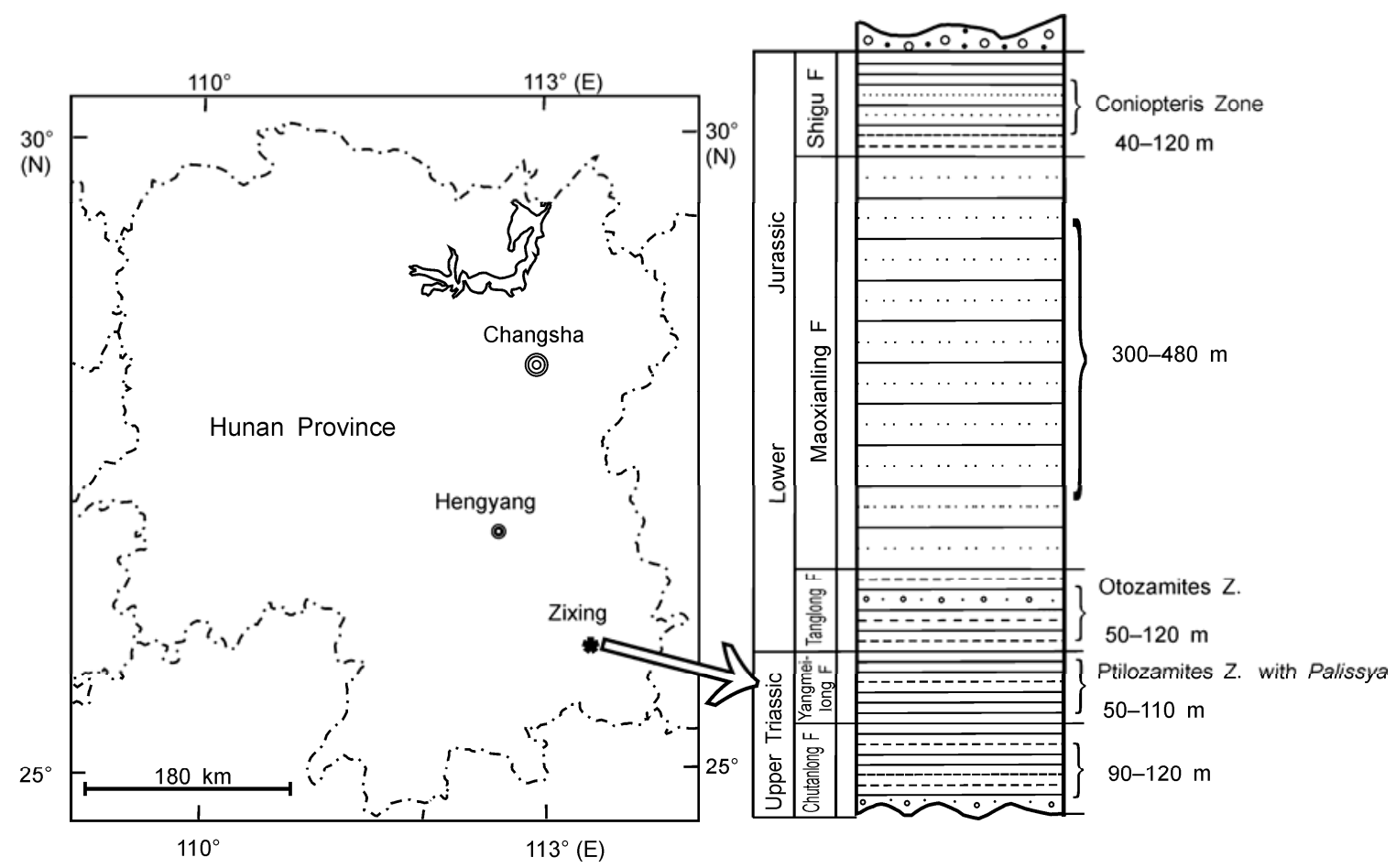

Figure 1 Maps of the locality and the stratigraphic section where the Palissya hunanensis (sp. nov.) specimens were collected.

\section{Systematics and diagnosis}

Order Coniferales

Family Palissyaceae

Genus Palissya Endlicher

Species Palissya hunanensis sp. nov.

Etymology: The species is named after the fossil locality in Hunan Province of China.

Specimens and repository: Five specimens in total assigned to the new Palissya species are stored at No. 4, 8th Road, Dazhigu, Tianjin 300170. These specimens include the holotype (No. Pal-149) with its counterpart (No. Pal-150) and three other specimens (Nos. Pal-145, Pal-151, and Pal-152), all coming from same block of black shale.

Specific diagnosis: Ovulate cone, loosely organized and small, up to $50 \mathrm{~mm}$ long (rarely $80 \mathrm{~mm}$ ) and $17 \mathrm{~mm}$ in diameter, and consisting of a striated main axis and numerous female dwarf shoots, each subtended by a bract. Female dwarf shoots mostly helical in arrangement or somewhat diplostichous, each with a thick axis strongly decurrent on main axis surface at base. Bracts lanceolate in shape, thin in texture, often with a short tip extending beyond bract apex. Up to five pairs of seed scales attached adaxially to an axis. Axis generally robust, covered with numerous larger, smaller, and minute sterile scales at base and ending in an acute apex. Seed scales diverse in morphology, cup-like, barrel-shaped or asymmetrically arch-shaped, distally often forming a thin wing. Ovules or seeds enclosed in seed scales. Mature seeds obovoid, about $1 \mathrm{~mm}$ in diameter, showing a bulged, smooth surface and a rounded distal edge, and ending in an acuminate base. Accompanying vegetative shoot of $50 \mathrm{~mm}$ long showing needles sparsely arranged, about $10 \mathrm{~mm}$ long and $1.5 \mathrm{~mm}$ wide. Needles flat or slightly vaulted on their upper sides, with a clear mid-vein.

\section{Description}

The best preserved specimen of the new Palissya (the holotype) is illustrated in Figure $2 \mathrm{a}$ and $\mathrm{d}$ with its counterpart specimen in Figure $2 \mathrm{f}$. This is a nearly complete ovulate cone. It is loosely organized like a flattened ovulate branchlet rather than a closely cylindrical cone. The cone measures $35 \mathrm{~mm}$ long and $13 \mathrm{~mm}$ wide at its base, and consists of a very thick main axis covered with 1-2 rigid ribs and 18 or so fertile organs, i.e. female dwarf shoots, mostly in helical attachment to the main axis at an angle of $40^{\circ}-60^{\circ}$ or in somewhat diplostichous arrangement. Each dwarf shoot is subtended by a bract and is made up of a robust axis and 4-5 pairs of seed scales borne erectly on it. Bracts are about $8.5 \mathrm{~mm}$ long and $2 \mathrm{~mm}$ wide at the middle; elongate-lanceolate with thin, slightly concave blades, tapering toward the apex or sometimes ending in a pointed tip; and apparently contracted at their bases but not forming a stalk. At the cone apex, the bracts are short and small, about $5 \mathrm{~mm}$ long and $1.5 \mathrm{~mm}$ wide, extending outward at an acute $\left(<30^{\circ}\right)$ angle. In preservation, most of the bracts are laterally impressed and often indiscernible, so that the female dwarf shoots appear as a robust axis to which many arched-shaped wings, about $1.5 \mathrm{~mm}$ long and $1 \mathrm{~mm}$ wide, are adaxially attached. Apparently, the axis is strongly decurrent on the main axis 


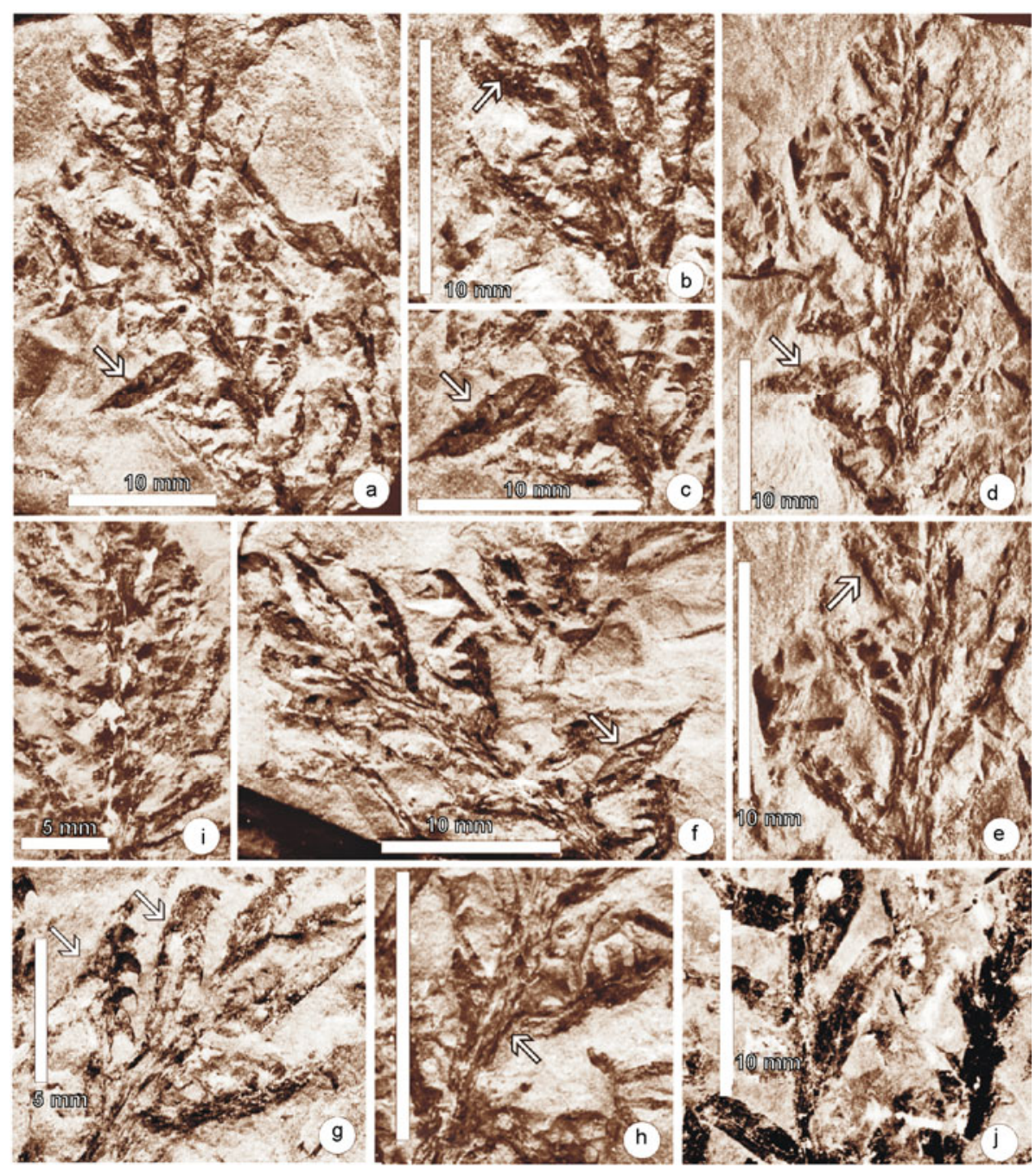

Figure 2 Palissya hunanensis (sp. nov.). Ovulate cones: a-e show a nearly complete cone, lacking only its base, No. Pal-149 (holotype). a and c, d show the same bract (arrows) under different angles of reflected light; b and e (arrows) show the apical part of the cone at different angles of reflected light. f-h show the counterpart to the holotype, No. Pal-150: $\mathrm{f}$, a bract (arrow) also occurs in a corresponding position, underlying a female dwarf shoot; g, apical part of the cone, showing two flat-preserved bracts with a blade on which some cup-like seed scales clearly lie in two rows (arrows); h, lower part of the cone, showing an axis (arrows) directly decurrent on the main axis. i, another incompletely ovulate cone showing many female dwarf shoots plus bracts mostly in apparently diplostichous arrangement, No. Pal-147. j, part of a sterile shoot (left) is associated with an unconnected ovulate cone (right) of Palissya hunanensis (sp. nov.), No. Pal-152.

surface at the base (Figure $2 \mathrm{~h}$, arrow). The bract blades are extremely thin and thus often indistinct or not visible on the images of the cone, but they can be clearly visible when the angles of reflected light are adjusted under the microscope (Figure 2a, c, d, f, arrows).

Another ovulate cone (Figure 2i) exhibits a loose organization composed of bracts and narrower female dwarf shoots in apparently diplostichous arrangement around a straight, narrower main axis.

A fragment of sterile shoot (Figure $2 \mathrm{j}$, left), closely associated with but not connected to a Palissya ovulate cone (right), shows sparsely-arranged needles. Most of them are lanceolate, uni-veined leaves attached to a main axis. These are somewhat similar to the thin bract blade of the ovulate cone.
In most of the dwarf shoots, the two-rowed arrangement of the seed-scale pairs cannot be seen because they are mostly laterally impressed and look like a single row in preservation, and only few flat-preserved bracts on which the seed-scale pairs lie can be seen arranged in two rows, although they are not completely preserved (Figure $2 \mathrm{~g}$, arrows).

Some pieces of coaly substance were cleaved from the axis of the dwarf shoot that bears cup-like seed scales (Figure $2 j$, right). Subsequent SEM observation of this pieces revealed some previously unknown features of the seed scales and in situ seeds, as shown in Figure 3a-j.

Figure 3 a shows parts of two adjacent incomplete female dwarf shoots, overlapping each other; the lower one is a robust axis to which three obovoid bodies $\left(S_{1-3}\right)$ are found erectly attached. One of them (Figure $3 \mathrm{~b}, S_{1}$ ) has a smooth 

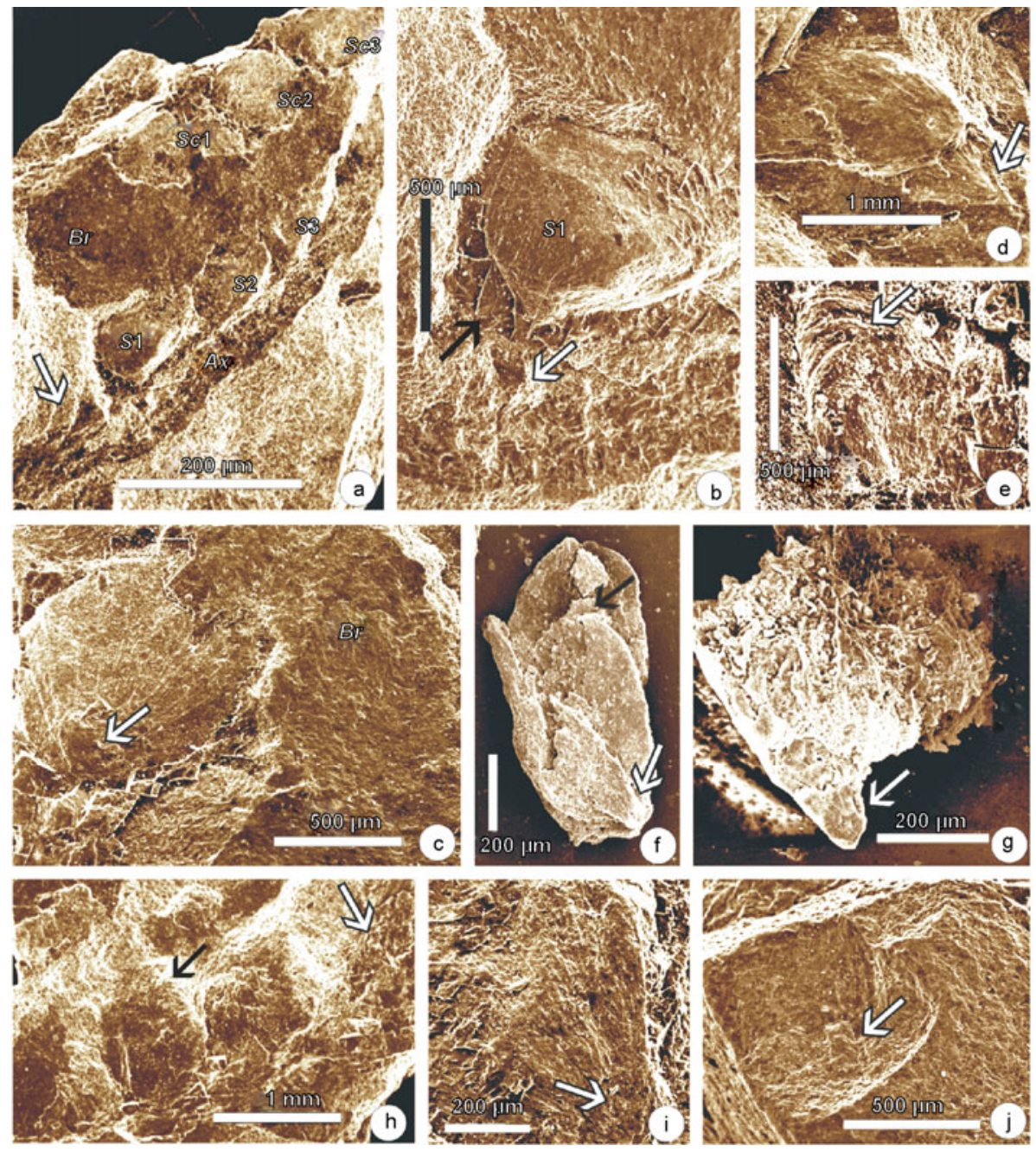

Figure 3 Microscopic details of Palissya hunanensis (sp. nov.) from the ovulate cone in the right side of No. Pal-152: a, below: part of a dwarf shoot with a thick, robust axis covered with small sterile scales at its base (arrow) and three seeds $\left(S_{1-3}\right)$ with stalk-like bases; above: piece of another dwarf shoot viewed from the bottom, showing three seed scales $\left(S c_{1-3}\right)$ partially covered by a thin bract blade $(B r)$; b, detail of the seed $S_{1}$ extending downward into a stalk-like base (arrow) almost attached to the robust axis. Note the dark areas (black arrow) covered with crack marks on both sides of the seed; c, detail of the seed scale $S c_{2}$ in bottom view, showing regular and radial lines on the surface and a solid proximal head (arrow). Minute dots (possibly hairs) occur on the surface of the thin bract $(B r)$; d, detail of a small, barrel-shaped seed scale in bottom view, showing coarse ribs running along its surface and a circular scar at bottom. Note the adjacent seed scale (arrow) with a tapering base; e, a seed scale, showing its inflected and plicate distal end (arrow); f, a remnant of a seed scale after bulk maceration, showing a seed scale (arrow) containing a seed. Note the seed apex contaminated with minute pieces of the scale wall (black arrow); g, another remnant of a complete seed scale after bulk maceration, showing a smooth, solid base (arrow, possibly an ovule) and a network-shaped distal part composed of branching, intermingled filaments. Note that the network does not extend to the solid base; $h$, another piece of a female dwarf shoot in lateral view, showing two seed scales attached adaxially to a thick axis (arrow). Note that the apices (black arrow) are inclined backward; i, a detached seed scale in lateral view showing a solid head (arrow) and a thinning, expansive distal wing; $\mathrm{j}$, a cleaved seed scale, showing a small protrusion extending upward (arrow)

surface and a broad distal edge and narrows basally into a short stalk-like structure. The seed base was highly likely connected to the axis (arrow). Moreover, the dark areas (black arrow) covered with crack marks at both sides of the seed can be interpreted as posterior walls of the seed scale that were exposed after the anterior wall facing the camera had been eroded. In addition, there are many minute sterile scales with acute tips adnate to the basal part of the axis (Figure 3a, arrow). In the upper portion of Figure 3a is part of another dwarf shoot with three seed scales in bottom view $\left(S c_{1-3}\right)$; each has a solid central head from which many dense, fine lines extend outward, radiating in all directions. In magnification, one of them (Figure 3c, i.e. Figure $3 \mathrm{a}, S c_{2}$ ) looks like a regularly rounded cap with fine radiating ornamentation on its surface. This ornamentation is a feature of seed scales that is of taxonomic significance.

Figure $3 \mathrm{~d}$ depicts a small barrel-shaped seed scale regularly covered with sparse but a coarse ribs and with a circular scar at its bottom. Another adjacent seed scale below it has an acuminate base (arrow). A flattened preserved seed scale shows an inflected and plicate distal portion (Figure $3 e$, arrow). Most notably, two isolated remnants of complete 
seed scales were obtained through bulk maceration and investigated with SEM microscopy (Figure $3 f-g$ ). Figure $3 f$ shows an asymmetrical seed scale (arrow) containing an ellipsoidal seed. Regrettably, several minute pieces of scale wall (black arrow) adnate to its apex might lead to the erroneous interpretation of a micropyle. Figure $3 \mathrm{~g}$ shows a complete seed scale consisting of a smooth, more or less contracted, solid base (arrow) and a network-shaped distal part made up of branching and intermingled filaments that do not extend onto the base.

Another piece of the dwarf shoot (Figure 3h) shows two bulged seed scales, in lateral view, attached erectly to a robust axis (arrow). The seed scale wall is also covered with regular fine lines but apically, the wall becomes much thinner in texture, forming an asymmetrical, somewhat backward inclined tip. A detached seed scale (Figure $3 \mathrm{i}$ ) has a solid proximate head (arrow) and a distally expansive wing apparently covered with radial lines and dots (possibly hairs). Figure $3 \mathrm{j}$ depicts a section across the lower part of a seed scale with a small protrusion (arrow), possibly the stalk-like base of a seed.

\section{Taxonomic comparisons}

At a glance, the new Palissya specimens are nearly identical with $P$. sphenolepis in that both share a basic organization. In some images (Figures $2 \mathrm{a}$ and 4), many of the female dwarf shoots clearly have a diplostichous arrangement with a robust axis base that is strongly decurrent on the main axis surface and with bracts that are barely visible. These can also be clearly seen in the illustrations of the European $P$. sphenolepis specimens, particularly the German ones [2]. Therefore, a somewhat diplostichous arrangement can be regarded as an important feature of the Palissya female dwarf shoots, which appear somewhat like dorsi-ventral structures.

However, Palissya hunanensis (sp. nov.) exhibits many features that distinguish it from $P$. sphenolepis (Figure 4). It has much smaller cones, thin bracts, and seed scales with diverse shapes, ranging from cup-like to barrel-shaped to asymmetrically arched and winged in shape. In addition, $P$. hunanensis has fewer (up to five) pairs of seed scales, all of which are different from those of $P$. sphenolepis and other

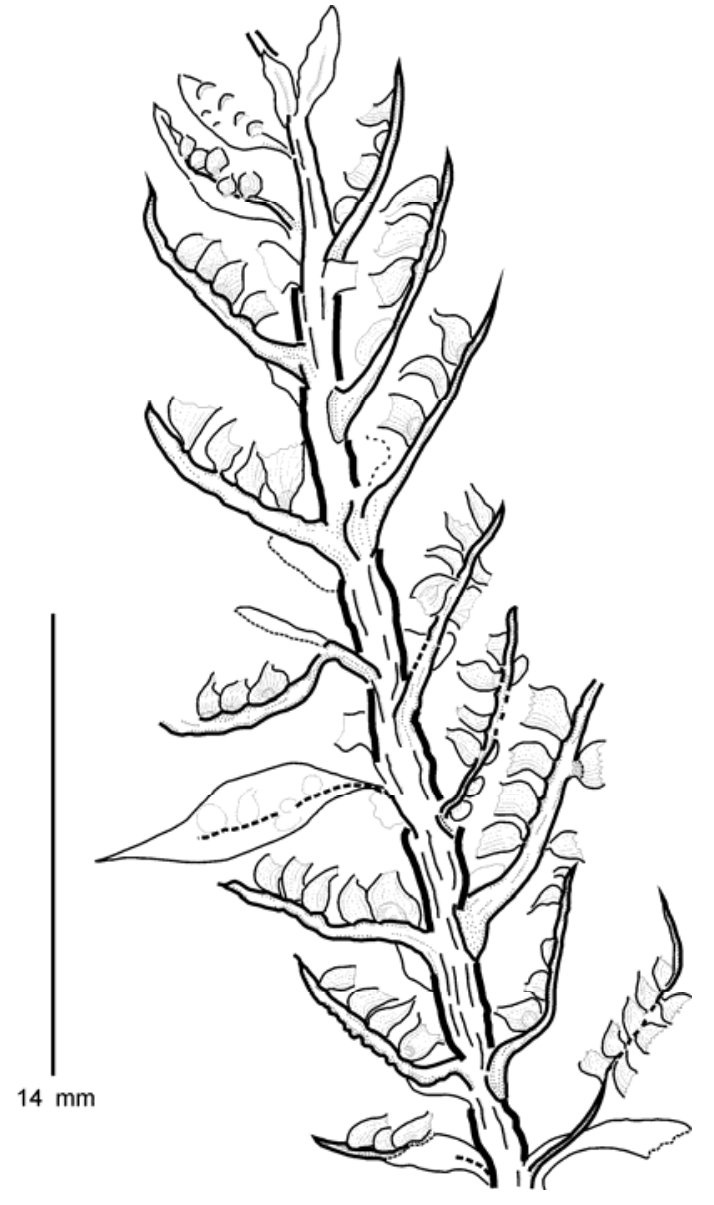

Figure 4 Camera lucida sketch of the holotype of Palissya hunanensis (sp. nov.).

members of the family, other than the seeds have stalked bases.

Most descriptions of the Palissyaceae of the Northern Hemisphere were made based on very few specimens from Sweden, Germany or America and thus, these data were obtained considerably at random sample. However, these specimens are the only reliable taxonomic material. Palissya hunanensis (sp. nov.) was also evaluated based on few (five) specimens, all of which came from a single block of rock. Nevertheless, all the measurements of $P$. hunanensis are distinctly smaller than those of the European species (Table 1).

Table 1 A comparison of the measurements of Palissya sphenolepis and P. hunanensis (sp. nov.) specimens

\begin{tabular}{|c|c|c|c|c|c|c|c|}
\hline Female cone & Length (mm) & Diameter (mm) & Main axis thickness (mm) & Bract length (mm) & Bract width (mm) & Seed scale pairs & Seed size $\left(\mathrm{mm}^{2}\right)$ \\
\hline P. sphenolepis* & $<100$ & $15-30$ & $<3$ & $10-15$ & $2-4$ & $5-6$ & $2.5 \times 2.0$ \\
\hline \multicolumn{8}{|c|}{ P. hunanensis (sp. nov.) } \\
\hline Pal-145 & 25 & 17 & 2 & $11-12$ & $2-3$ & $4(5)$ & $1.0 \times 0.8$ \\
\hline Pal-151 & 80 & 15 & $1.1-1.2$ & $3.5-4$ & 1 & $3-4$ & $0.8 \times 1$ \\
\hline Pal-152 & 50 & 10 & 2 & $5-6$ & 1.1 & $4-5$ & $0.7 \times 1$ \\
\hline
\end{tabular}

*Florin [9]. 
A noticeable feature of Palissya hunanensis (sp. nov.) that differs from the other members of the family is the thin texture of the bracts (Figure 2d, arrow) that can be discerned when the angles of the reflected light are altered (Figure 2a, arrow). In some of the SEM images, the bract blade is a thin, flat lamina covered with scattered minute dots (Figure 3c, Br). An acute but short distal extension of the bract often occurs beyond the axis, while in the European $P$. sphenolepis cones, the bracts tend to protrude beyond the axis by more than one third of the whole length [1,2]. American Metridiostrobus palissyaeoides has extremely thick bracts [3].

Under low magnification, the seed scales generally show asymmetrically winged forms (Figure 2c) in lateral view, or arched or circular ones in transverse view (Figure $2 \mathrm{~g}$ ). At higher magnifications, however, the seed scales exhibit more diversity in gross morphology: some take the shape of a cup or a cap (Figure 3c); others appear barrel-shaped (Figure 3d); some look like asymmetrically-expanding wing (Figures $3 \mathrm{~h}, \mathrm{i}$ ); and rarely one resembles a spoon containing a seed (Figure 3f, arrow).

In addition, the seed scales of one female dwarf shoot of Palissya hunanensis (sp. nov.) are very constant in number (not exceeding five), fewer than those of $P$. sphenolepis but more or less equal to those of Metridiostrobus palissyaeoides. The number of seed scales may be a significant character for the classification of Palissyaceae members.

The mature seeds of Palissya hunanensis (sp. nov.), although rarely found, are small in size, apparently bulged with a smooth surface, and have a stalk-like base and a distal, asymmetrical, rounded apex. These seeds do not fit the descriptions of the seeds of the Euramerican members of the family. The seeds of $P$. sphenolepis were depicted as flattened with a slightly-erect micropyle area [9], and the seeds of Metridiostrobus palissyaeoides were described to have a micropyle directed toward the bract margins [3].

A similar axillary structure was described as Palissya oleschinskii from the Lower Jurassic of Iran and was believed to be male cone of Palissya [33]. Although its age and erect axillary structure are the same as those of $P$. sphenolepis, its generic assignment lacks convincing evidence; in particular, the structure is unaccompanied by an ovulate cone of Palissya. In morphology, this fossil is a narrow, weakly cylindrical or catkin-like shoot that differs markedly from $P$. sphenolepis. It may be a pollen-bearing fructification of a pteridosperm.

A sterile shoot described as Elatocladus sp. from the early Liassic deposits in the Xiwan district of northwestern Guanxi, China, was compared to Palissya sphenolepis, but it lacks reproductive organs and has no epidermal structures [34], so its placement is uncertain.

In the Southern Hemisphere, several catkin-like reproductive organs referred to as "Palissya cones" were reexamined from the Middle Jurassic to the Lower Cretaceous strata at five to six localities in the eastern Australia and
New Zealand [4]. Most have narrow, cylindrical cones consisting of a fine, straight axis bearing many sporophylls radiating in all directions. In particular, two complete specimens of the cones clearly show a slender peduncle covered with scattered sterile scales. This kind of sporophyll has a narrow horizontal stalk attached directly to the cone axis at a right angle and distally, the sporophyll has expanded into a specialized "dentroit" structure consisting of paired, cupshaped adaxial processes subtended by a spoon-like blade. All of these features are taxonomically important, and these reproductive organs from the Southern Hemisphere are clearly distinguishable from those of Palissya sphenolepis and $P$. hunanensis of the Northern Hemisphere. These specialized structures may form the taxonomic basis for raising these Southern Hemisphere species to the generic (or higher) level [5].

Stratigraphic horizon and locality: The specimens originated in the Late Triassic Rhaetican Yangmeilong Formation in Sandou Mine of Zixing coal field, Hunan Province of China.

\section{Discussion and conclusions}

\subsection{Inconsistent usage of terminology for Palissya ovulate organs}

The terms used in the literature for Palissya ovulate cones have differed markedly among authors, particularly since the 1950s. Most authors followed Florin's terminology for the walchian conifers, but others preferred other terms because of equivocal evidence of seeds. Apparently, the terminologies reflect to some extent the different interpretations of the authors on the nature and affinities of the Palissya reproductive organ (Table 2).

To consider an extreme case, Florin's interpretation of the Palissya cone organization and his attribution of the cones to conifers have been strongly rejected in the literature, consequently, anything Palissya structure reputed seed has not been accepted. Some Australian authors refer to the seed scale as an "adaxial process" [4]. Others threw doubts on the coniferous affinity of Palissya $[6,15]$. Since the publication of Florin's monographs on conifers and taxads [2,8,9], Palissya and other early conifers with specialized "seed-scale complexes" have been interpreted in distinctly different ways. Stewart and Rothwell still used "ovuliferous scale" rather than the "seed-scale complex" [16]. Delevoryas and Hope did not use Florin's concept for Metridiostrobus palissyaeoides [3], rather they suggested that the Metridiostrobus cone with an arillate structure, termed an "ovule-bearing appendage complex", might be homologous to the voltzialean fertile dwarf-shoot, a thought shared by Taylor [13]. Of note, Taylor and Taylor introduced the concept of a "bract-scale complex" [14], but this would weaken the meaning of the compound structure of the Palissya cones. 
Table 2 Inconsistent terminology applied to Palissya ovulate organs

\begin{tabular}{llll}
\hline \multicolumn{1}{c}{ Authors } & Ovulate organ & \multicolumn{1}{c}{ Bract } & Ovuliferous organ \\
\hline Schenk & weiblich Zapfen & Zapfen Schuppe & Cupule (Becker) \\
Nathorst & weiblich Zapfen & Zapfen Schuppe & Samenbecher \\
Seward & megastrobili & Sporophyll (bract) & cupule \\
Florin & weiblich Zapfen & Deckschuppe & Samenschuppen Komplex \\
Florin & female cone & bract & seed-scale complex \\
Delevoryas \& Hope & ovulate cone & bract & ovule-bearing appendage \\
Taylor \& Taylor & ovulate cone & cone scale & bract-scale complex \\
Meyen & female cone & bract & compound polysperm \\
Stewart \& Rothwell & seed cone & bract & ovuliferous scale \\
Parris et al. & cone & sporophyll & adaxial process \\
Taylor et al. & ovulate cone & bract & bract-scale complex
\end{tabular}

7.2 SEM observations of Palissya hunanensis (sp. nov.) seed scales reveals a specialized seed carrier

Like other poorly-preserved material of Palissyaceae, Palissya hunanensis (sp. nov.) is established as a new species based on very few and incomplete specimens that lacked microstructural data. An SEM morphological investigation provided some significant evidence for seed scales and seeds, increasing our knowledge of the genus.

The seed entity of Palissya has a prominent body with a smooth surface, a rounded apex edge, and a stalk-like base (Figure $3 b$ ). The discovery of mature seeds (Figure 3b, f) is of significance, indicating that the seed may have developed in the seed scale. The seed scale often has a specialized structure, i.e. a solid head at its proximal end (Figure 3c,i), where an ovule or an immature seed might have developed.

In addition, the stalk-like seed base (Figure 3b,j, arrows) is a distinctive structure attaching the mature seed to the axis. Importantly, the stalk-like base of the P. hunanensis (sp. nov.) seed and its adaxial attachment to the axis is consistent with Florin's interpretation of an erect or inverted ovule for the Ernestiodendron type of walchian conifer [2]. This lends support to Florin's concept of a bract plus seed-scales complex as a general organizational plan for conifer ovulate cones.

In some of the SEM images of the seed carriers (i.e. seed scales; Figure 3a,b,h, arrows), they are clearly found attached to a thick, robust axis rather than directly to a thin bract blade covering the axis. Other images (Figure 3c,d) depict seed scales with ornamentation of dense, fine, straight linear rays or ribs, very similar to the Swedish material [1] and unlikely to be the cellular structures of walls [4].

\subsection{Affinities of the Palissya ovulate cone}

Almost all authors considered Palissya fossils to be the reproductive organs of an extinct plant, and most, except for Parris et al. [4], attributed it to Coniferales following Florin's classification [2]. After paying special attention to the shoot architecture and epidermal structures, Florin established a new family, Palissyaceae, to accommodate Palissya and Stachyotaxus, which appeared to be closely related to one another [9]. The cuticular structures of Stachyotaxus from the Late Triassic floras of East Greenland were studied in detail by Harris, who supported the genus as a specialized extinct conifer closely related to Palissya [7]. Since then, most authors, particularly those of the TN Taylor school $[13,14,17]$, have expressed basic agreement with Florin's taxonomy of Palissyaceae. Even Parris et al. [4] had to admit that Stachyotaxus "may indeed be a compound structure related to a conifer cone", but they still held that Stachyotaxus would probably have their reputed "adaxial process" as its sporophyll.

During the second half of the last century, Florin's hypothesis on Paleozoic walchian conifers was strongly rejected $[19,20]$, but not completely overthrown, and underwent major revisions [35]. Notably, during the past ten years, the Paleozoic walchian conifers were elaborated in all directions. Various pieces of information about foliage, male and female cones, cuticular structures, and anatomical or other microstructures [36,37] have been accumulated and updated to a high step using modern approaches. As a result, Florin's concept may indeed be of resurgence. The ovulate cones of Palissya have proved to be compound structures. Compared to the walchian conifers, the Palissya ovulate cone exhibits the same basic organizational plan composed of a main axis with many axillary dwarf shoots attached, each subtended by a bract.

Interestingly, a new type of conifer cone, Lebowskia grandifolia, has been described for some specimens from the lower Upper Permian in Texas, USA [38]. These specimens suggest a strong affinity to the uppermost Triassic Palissyaceae. The Lebowskia cone consists of a basic structure described by Looy [38] as a "dwarf shoot-bract complex", similar to that of the Palissya cone, which includes concave bracts and axillary dwarf shoots, both helically attached to a cone axis. However, the Lebowskia dwarf shoots consist of five partially-fused scales, a stalk-like base, and simple seeds, rather than seed pairs as in Palissya, that are laterally (possibly also adaxially) attached. Thus, they are distinguishable from Palissya hunanensis (sp. nov.) and any other members of Palissyaceae. 


\subsection{Ecology of the Palissya conifers}

In the Northern Hemisphere, all members of Palissyaceae, except for the American Metridiostrobus palissyaeoides, were found from nearly contemporaneous deposits that spanned a short interval of geologic time, i.e. the Late Triassic Rhaetican age. They appear to have inhabited similar ecological environments, as they are correlated with coal seams, co-occur with marine fauna, and also accompany other wetland fossil plants $[1,3,7,18]$. These plants include ferns with large fronds, Taeniopteris-type foliage, other seed plants (bennettitaleans, cycads, seed-ferns), and other small conifers. These patterns suggest that the Palissya-type conifers were small bushes that grew in tropical-subtropical swampy peat (coal) environments in scattered, continental-marine wetland habitats. Fossil floras with such floristic compositions constituted a specialized biotic zone during the Late Triassic Rhaetican age referred by Zhou to as the "Maritime Floristic Province". It extended from East Greenland to south China [30,34]. If this interpretation is correct, the Palissya-type conifers are ecologically different from other conifers, both extinct and extant, that mostly grow in drier or upland habitats.

I am especially grateful to Prof. Zhou Zhiyan for many suggestions on the manuscript and for linguistic help, also to another anonymous reviewer for useful comments, to Dr. Wang Yan of the Key SEM-Laboratory of the Analyses Centre of Tianjin University, for preparing SEM photographs, and to the Key SEM-Laboratory of the Nanjing Institute of Geology and Paleontology, CAS, for help with the digital images.

1 Nathorst A G. Paläobotanische Mitteilungen 7: Uber die Gattung Palissya, Stachyotaxus, Palaeotaxus. Kungl Svenska Vet-Akad Handl, 1908, 43: 1-20

2 Florin R. Die Koniferen des Oberkarbons und des unteren Perms. Palaeontogr Abt B, 1944, 85: 457-654

3 Delevoryas T, Hope R C. More evidence for conifer diversity in the Upper Triassic of North Carolina. Am J Bot, 1981, 68: 1003-1007

4 Parris K M, Drinnan A N, Cantrill D J. Palissya cones from the Mesozoic of Australia and New Zealand. Alcheringa, 1995, 19: 87-111

5 Pattemore G A. A new Early Jurassic pteridosperm fructification from Queensland. J Afr Earth Sci, 2000, 31: 187-193

6 Seward A C. Fossil Plants IV. Cambridge: Cambridge University Press, 1919

7 Harris T M. The fossil flora of Scoresby Sound, East Greenland. Part 4: Ginkgoales, Coniferales, Lycopodiales and isolated fructifications. Med õm Grønland, 1935, 112: 1-176

8 Florin R. Evolution in cordaites and conifers. Acta Horti Berg, 1951, 15: 285-388

9 Florin R. On Jurassic taxads and conifers from northwestern Europe and eastern Greenland. Acta Horti Berg, 1958, 17: 259-388

10 Arnold C A. An introduction to Paleobotany. New York: McGrawHill, 1947

11 Gothan W, Weyland H. Lehrbuch der Paläobotanik. Berlin: Akademie Verlag, 1954

12 Kryshtofovich A N. Palaeobotany (in Russian). Leningrad: Gostoptekhizdat, 1957

13 Taylor T N. Paleobotany: An Introduction to Fossil Plant Biology.
New York: McGraw Hill, 1981

14 Taylor T N, Taylor E L. The Biology and Evolution of Fossil Plants. Englewood Cliffs New Jersey: Prentice Hall, 1993

15 Meyen S V. Fundamentals of Palaeobotany. London: Chapman \& Hall, 1987

16 Stewart W N, Rothwell G W. Paleobotany and the Evolution of Plants. 2nd ed. New York: Cambridge University Press, 1993

17 Taylor T N, Taylor E L, Krings M. Paleobotany. The Biology and Evolution of Fossil Plants. 2nd ed. San Diego: Academic Press, 2009

18 Harris T M. Rhaetic floras. Biol Rev, 1931, 6: 133-162

19 Schweitzer H-J. Der weibliche Zapfen von Pseudovoltzia liebeana und seine Bedeutung für die Phylogenie der Koniferen. Palaeontogr Abt B, 1963, 113: 1-29

20 Clement-Westerhof J A. Morphology and phylogeny of Paleozoic conifers. In: Beck C B, ed. Origin and Evolution of Gymnosperms. New York: Columbia University Press, 1988. 298-337

21 Crane P R. Phylogenetic analysis of seed plants and the origin of angiosperms. Ann Mo Bot Gard, 1985, 72: 716-793

22 Doyle J A, Donoghue M J. Seed plant phylogeny and the origin of angiosperms: An experimental cladistics approach. Bot Rev, 1986, 52: $322-431$

23 Rothwell G W, Serbert R. Lignophyte phylogeny and the evolution of Spermatophytes: A numerical cladistic analysis. Sys Bot, 1994, 19: $443-482$

24 Nixon K C, Crepet W L, Stevenson D, et al. A reevaluation of seed plant phylogeny. Ann Mo Bot Gard, 1994, 81: 484-533

25 Doyle J A. Seed plant phylogeny and the relationships of Gnetales. Int J Plant Sci, 1996, 157(Suppl.): S3-39

26 Axsmith B J, Taylor T N, Taylor E L. A new fossil conifer from the Triassic of North America: Implications for models of ovulate cone scale evolution. Int J Plant Sci, 1998, 159: 358-366

27 Miller Jr C N. Implications of fossil conifers for the phylogenetic relationships of living families. Bot Rev, 1999, 65: 239-277

28 Harris T M. The evolution of the conifer cone. New Phyt, 1947, 46: 174-177

29 Rothwell G W, Mapes G. Barthelia furcata gen. et sp. nov., with a review of Paleozoic Coniferophytes and a discussion of Coniferophyte systematics. Int J Plant Sci, 2001, 162: 637-667

30 Chen J H, Zhou Z Y, Pan H Z, et al. On the Mesozoic coal series and its faunas and floras in southwestern Hunan (in Chinese). Bull Nanjing Inst Geol Palaeontl Acad Sin, 1980, 1: 76-98

31 Chen Z H, Wu S B, Lu R L, et al. On conditions of deposition for Mesozoic strata and ages of Tanglong and Shigu formations in Sandu, Hunan. Earth Sciences-J Wuhan Col Geol, 1982, (18): 143-154

32 Fang Z J, Wang L, Liang C L, et al. New advances of the Mesozoic coal-bearing deposits in Zixing, Sandu district, Hunan. J Stratigr, 1989, 13: 193-204

33 Schweitzer H J, Kirchner M. Die rhäto-Jurassischen Floren des Iran und Afghanistans: 9. Coniferophyta. Palaeontogr Abt B, 1996, 238: $77-139$

34 Zhou Z Y. Early Liassic plants from Southwest Hunan, China. Palaeontol Sin NSA, 1984, 7: 1-85

35 Mapes G, Rothwell G W. Permineralized ovulate cones of Lebachia from Late Palaeozoic limestones of Kansas. Palaeontology, 1984, 27 : 69-94

36 Hernandez-Castillo G R, Rothwell G W, Mapes G. Thucydiaceae fam. nov., with a review and reevaluation of Paleozoic walchian conifer. Int J Plant Sci, 2001, 162: 1155-1185

37 Hernandez-Castillo G R, Stockey R A, Rothwell G W, et al. Reconstructing Emporia lockardi (Voltziales: Emporiaceae) and initial thoughts on Paleozoic conifer ecology. Int J Plant Sci, 2009, 170: 1056-1074

38 Looy C V. Extending the range of derived Late Paleozoic conifers: Lebowskia gen. nov. (Majonicaceae). Int J Plant Sci, 2007, 168: 957972

Open Access This article is distributed under the terms of the Creative Commons Attribution License which permits any use, distribution, and reproduction in any medium, provided the original author(s) and source are credited. 